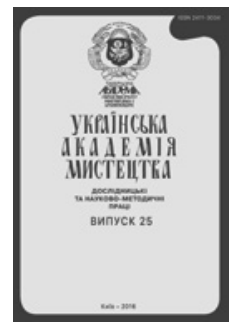

№27 (2018) стор. 200-207

The National Academy of Fine Arts and Architecture

Ukrainian Academy of Fine Art. Research and Methodology Papers

ISSN 2411-3034

Website: http://naoma-science.kiev.ua/

УДК 7.075

ID ORCID 0000-0001-8011-4216

DOI: https://doi.org/10.33838/naoma.27.2018.200-207

\title{
Борис Платонов
}

доктор технічних наук, стариий науковий співробітник, оиінювач, дочент кафедри теорії та історії мистеитва НАОМА boris.platonov@gmail.com

\section{ПРИБУТКОВІСТЬ ТВОРІВ МИСТЕЦТВА: МОДЕЛІ, РОЗРАХУНКИ, УКРАЇНСБКИЙ СЕГМЕНТ РИНКУ}

\begin{abstract}
Анотація. Описано новий варіант методу повторних продажів, який використовується аналітиками арт-ринків, а також оцінювачами при оцінці вартості творів мистецтвв порівняльним підходом. Модель, щุо покладена в основу и̧ього варіанту, спрощує проведення необхідних розрахунків, зберігаючи при изьому потрібну точність. Із залученням даних із всесвітньовідомого сайту Artprice представлені результати обчислення рейтингів економічної успішності на арт-ринках деяких провідних украӥнських художників.
\end{abstract}

Ключові слова: твори мистецтва, метод повторних продажів, експоненціальна модель зростання вартості, український сегмент арт-ринку.

ДОХОДНОСТЬ ПРОИЗВЕДЕНИЙ ИСКУССТВА: МОДЕЛИ, РАСЧЕТЫ, УКРАИНСКИЙ СЕГМЕНТ РЫНКА.

Борис Платонов

Аннотация. В работе описывается вариант метода повторных продаж, который используется аналитиками арт-рынков, а также оченщиками в рамках сравнительного подхода при оценке стоимости произведений искусства. Модель, положенная в основу этого варианта, упрощает проведение необходимых расчетов, сохраняя при этом требуюшуюся точность. С привлечением данных с всемирно известного сайта Artprice представлены результаты вычисления рейтингов экономической успешности на арт-рынках некоторых ведущих украинских художников.

Ключевые слова: произведения искусства, метод повторных продаж, экспоненциальная модель роста доходности, украинский сегмент арт-рынка.

INCREASE OF ART CREATIVES: MODELS, CALCULATIONS, UKRAINIAN SEGMENT OF THE MARKET.

Borys Platonov

Abstract. The paper describes a variant of the repeat sales methodology, used by art market analysts, as well as appraisers using comparative approach in assessing the value of works of art. Here we describe a new model aimed to, streamline the necessary calculations while maintaining the accuracy at the required level. We ranked economic success of the works of certain famous Ukrainian artists using data from the Artprice web-based resource (https:// 
www.artprice.com). Included in the analysis were the sales outcomes reported by international art auctions for artworks from a certain part of the Soviet period and of contemporary Ukrainian artists. The ranks of the top ten masters of Ukrainian social realism in Ukrainian art market were compared to sale prices of works of 22 contemporary Ukrainian artists in international art auctions. The sample for the latter is made with more than 500 sales including very recent ones made in 2017. Comparison of these data with the results for TOP90 of the world's most expensive art sales in 2016 indicates lower demand for Ukrainian artists in the context of world top sales. However, the dynamics of profitability of Ukrainian works over time is overall positive. Methodology. Based on the model of cash deposit value growth in time, the author uses the method, well-known to appraisers, that allows to calculate the profit from movable property by analogy with the profit from a bank deposit. The basis for calculations is the data on the sale of the most expensive 100 paintings of 2016 year, as well published in web-based resource (https://www.artprice.com). Keywords: artwork, repeat sales method, exponential model of profit growth, Ukrainian art market.

Постановка проблеми. Міжнародний ринок культурних цінностей швидко набуває нових рис. $3 \mathrm{i}$ звичайного об’єкта інтересу колекціонерів він перетворюється на повноцінний інвестиційний ринок із власною інфраструктурою, законами функціювання, аукціонними домами, галереями, арт-дилерами, кураторами, посередниками, експертами, оцінювачами, університетською професурою. Культурні цінності, згідно з класифікацією ЮНЕСКО, мають дуальну природу: художню й економічну цінність водночас. Якщо при визначенні першої можна скористатися відомими традиційними, якісними характеристиками, то щодо другої обійтись без визначення кількісних характеристик неможливо.

Зв'язок авторського доробку з важливими науковими та практичними завданнями. Серед усієі сукупності суб’єктів арт-ринків вирішенням подібних питань займаються фінансові аналітики й оцінювачі. 3 рекомендованих міжнародними стандартами оціночних підходів найбільш адекватним для оцінки культурних цінностей треба вважати порівняльний. Адже тільки із застосуванням його методів можливо відшукати, або побудувати віртуальні, об'єкти-аналоги, що забезпечать визначення вартості об'єкта оцінки, навіть якщо він існує в єдиному примірнику, як це буває дуже часто з творами мистецтва. Але відомі методи порівняльного підходу тяжіють до універсальності, що не завжди є позитивом, особливо коли оцінюються твори мистецтва, які мають суто індивідуальні характеристики. Тому є потреба в удосконаленні інструментів їхнього кількісного виміру.

Аналіз досліджень та публікацій. Методам порівняльного підходу загалом присвячено багато публікацій, але стосовно визначення вартості творів мистецтва їх маємо обмаль. Серед інших виді- ляється багатопланова праця відомого дослідника арт-ринку професора Д. Тросбі (Throsby 1-29).

Варті уваги також роботи: J. Pesando (присвячена моделюванню прогнозів 3 використанням «мереж Маркова»), та «Art as an Investment and Conspicuous Consumption Good By Benjamin R. Mandel» (присвячена моделюванню прогнозів на підставі теорії ризиків інвестицій). А Т. Ратнікова, О. Сергєєва, M. Arvin, M. Scigliano - заторкують виміри гедонічної цінової функції тощо. До вітчизняного вкладу в дослідження методів порівняльного підходу можна віднести, наприклад, публікації Б. Платонова та В. Мазур, присвячені застосуванню експоненціальної моделі зростання вартості ЕМЗ. Буде доцільним згадати й експериментальні результати виконаних під керівництвом автора в 2017 і 2018 роках магістерських робіт Л. Дубовецької та $€$. Ігнатова. Методологічні пошуки відповідей на деякі питання з кількісними прогнозами є у вельми цікавих $\mathrm{i}$ грунтовних працях П. Доссі та Ф. Хука.

Деякі невирішені раніше частини проблеми, яким присвячується стаття. Загалом методи порівняльного підходу при оцінці культурних цінностей можна поділити на два класи: коли об'єкт оцінки й об'єкт-аналог відрізняються за однією властивістю, і такі, де наявна відмінність у більшій кількості властивостей. Раніше нами вже розглядався подібний поділ на класи, і для першого класу об'єктів було запропоновано метод визначення оцінювальної вартості на підставі нормального (Гаусового) закону розподілу відмінностей (Платонов 68). Отже, до першого класу можна віднести такі культурні цінності, як, наприклад, монети, що можуть відрізняться одна від одної тільки ступенем зносу, поштові марки, деякі види зброї, нагороди, грошові знаки, цінні папери 
та багато інших об’єктів «масового» виготовлення, що привертають увагу колекціонерів.

Для об’єктів другого класу найширше застосування мають інші методи, які умовно можна поділити на два типи. Перший тип пов'язаний з оцінюванням вартості на основі гедонічної регресії, коли передбачається, що вартість у процесі продажу, наприклад картини, залежить як від попередніх результатів їі продажу, так і від набору специфічних характеристик: розміру картини, стилю, техніки, матеріалу основи, стану збереженості, аукціонного будинку, в якому відбувається продаж тощо.

Подібний метод дозволяє досконало визначити різноманітні параметри об'єкта, істотно збільшити кількість можливих аналогів, але при цьому серед дослідників відсутня єдина думка щодо універсальності набору характеристик, які варто вивчати. Обчислення, що провадяться при застосуванні цього методу, як правило, громіздкі й не завжди виправдані.

Другий тип повторних (не менше двох) продажів полягає в тому, що прибутковість від продажу картини того чи іншого художника визначається тільки на підставі ціни попереднього продажу, а специфічні характеристики картини (розмір, автор, матеріал тощо) ігноруються, оскільки, на думку прихильників цього методу, не можуть бути враховані повною мірою. Наприклад, у дослідженні Вільяма Баумоля (Baumol 1-14) застосовується різновид методу, коли до уваги беруться тільки ціни двох продажів, здійснених не менше як через 20 років один після одного (автор методу вважає, що це дозволяє запобігти можливому впливу спекулятивних тенденцій на ринку). Користуючись набором даних за 309 років - з 1652 до 1961 року - В. Баумоль розрахував, що реальна норма прибутку по середньостатистичному вкладу в картини склала 0,6\% (реальна норма прибутковості по безризикових облігаціях британського уряду за той же період становила 2,5\%).

Наукова новизна дослідження. Відомі методи, в тому числі зазначені у В. Баумоля, оперують 3 реальними продажами, але при цьому є досить складними при підготовці даних для розрахунків. Тому нами було запропоновано різновид методу, що значно спрощує їх, коли за ціну повторного продажу обирається не реальна, а віртуальна, обчислена на базі експоненціальної моделі зростання вартості (ЕМ3) величина, адже нами було ви- значено, що зростання вартості творів мистецтва у часі підпорядковується саме експоненціальному законові (Платонов, Мазур 106). Можливо, точність розрахунків при такому варіанті обчислень прогнозу нижча, порівняно з методом В. Баумоля, але розрахунки значно простіші, до того ж великим «плюсом» варіанту є можливість розрахунків для будь-якого необхідного періоду змін, що дуже часто викликана практичною потребою.

Методологічне значення авторської розробки. Формула визначення вартості можливого повторного продажу: $\mathrm{S}^{\mathrm{n}}=\mathrm{S}_{0 \mathrm{e}}{ }^{\mathrm{pn} / 100}(1)$, де

$\mathrm{S}^{\mathrm{n}}$ - прогнозована вартість повторного продажу через п років;

$\mathrm{S}_{0}$ - початкова ціна твору (ціна за стандартами оцінювачів, на відміну від вартості, характеризує факт, що відбувся);

$e$ - константа, що дорівнює величині 2,71;

$\boldsymbol{p}$ - річна швидкість зростання вартості, визначена у відсотках (в моделі ЕМЗ вона дорівнює ставці банківського депозиту) (Платонов, Мазур 106).

Формула, що дозволяє розв'язати зворотну задачу визначення річної швидкості зростання вартості р при відомих початковій та майбутній вартості, має вигляд:

$p=100 \ln \left(S^{n} / S_{0}\right) / n(2)$,

де зміст змінних такий самий, як у формулі (1), а ln - символ натурального логарифму.

Виклад основного матеріалу. На підставі формули (2) з'явилася можливість порівняти дані 1961 року, отримані В. Баумолем, з сучасною прибутковістю станом на 2016 рік, тобто за 55 років. Таке порівняння має на меті: по-перше, показати дієздатність моделі ЕМЗ та, по-друге, простежити динаміку зміни вартостей за цей період. У ролі первинних у розрахунках залучені дані з сайту Artprice. Наразі бази даних Artprice не мають реальних конкурентів. Майже $80 \%$ аукціонних будинків по всьому світові складають свої каталоги згідно з базами даних Artprice, використовуючи дані про художників, ціни, індекси і провенанси робіт. У базах даних понад 30 мільйонів записів, включно з 620000 імен художників, 36000 взірців підписів, біографіями 120000 художників, аналітичні й довідкові матеріали тощо. Доступ до цих даних є платним. Природно, що на сайті наявна вичерпна інформація про продажі робіт українських художників. 
Таблиия 1. Зростання вартості ТОП-100 картин 2016 року

з розрахунку величини р не більше 20\% (Ігнатов 59)

\begin{tabular}{|c|c|c|c|}
\hline $\begin{array}{c}\text { Річна швидкість } \\
\text { зростання вартості } \mathrm{p}, \%\end{array}$ & Кількість картин & $\begin{array}{c}\text { Питома вага } \\
\text { 3 90 картин, } \%\end{array}$ & $\begin{array}{c}\text { Вік твору до продажу, } \\
\text { років }\end{array}$ \\
\hline 10 & & & $92-113$ \\
\hline 13 & & & $70-99$ \\
\hline 11 & & & $85-96$ \\
\hline 9 & & & $106-125$ \\
\hline 7 & & & $124-142$ \\
\hline 20 & & & $40-52$ \\
\hline 18 & & & $52-58$ \\
\hline 17 & & & $55-61$ \\
\hline 14 & & & $65-67$ \\
\hline 12 & & & $74-84$ \\
\hline 3 & & & $306-403$ \\
\hline 1 & & & $678-716$ \\
\hline 19 & & & $50-54$ \\
\hline 15 & & & $60-65$ \\
\hline 2 & & & $416-486$ \\
\hline & & & \\
\hline
\end{tabular}

У проведеному нижче аналізі використані найостанніші відомості за 2016 рік. Із сайту Artprice було залучено дані продажів на всесвітніх аукціонах ТОП-100 творів з найвищими цінами. Серед них $є$ десять скульптур, відомості про які в подальшому не були враховані, тобто у списку залишилося 90 картин. Згідно з формулою (2) для всіх обраних картин на підставі даних про їхній вік були розраховані річні швидкості зростання вартості (p). Результати розрахунків наведені в табл. 1 .

Аналогічно В. Баумолю, який зробив обмеження в розрахунках для періоду повторного продажу «не менше 20 років», було введено обмеження на залучення до розрахунків картин, значення річної швидкості зростання вартості р яких становило понад $20 \%$ річних. Загальновідомо, що відсотків банківських депозитів подібної величини не буває, тому логічно вважати, що й порівнювати немає з чим.

Таблиця 1 ілюструє, «що сумарна кількість картин, які мають значення р від 7\% до $13 \%$, становить $27 \%$ з усіх 90 картин. Результат р не вищий $20 \%$ річних має ще 30\% картин списку, тобто з 90 картин $57 \%$ мають величину р від $1 \%$ до 20\% річних» 8 ) (Ігнатов 5. При обмеженнях, подібних до введених
В. Баумолем, середньорічна (2016 року) величина річного зростання вартості ТОП-100 картин дорівнює 11,33 . Цікаво, що вона не набагато (різниця 1\%) перевищує показник 10,58, визначений для творів мистецтва як найбажаніший (Платонов, Мазур 106). Але, порівняно з результатом В. Баумоля, ця величина $€$ значно більшою. Чинниками подібного зростання, на наш погляд, $є$ те, що до аналізу залучені найдорожчі твори (нам невідомий принцип відбору В. Баумоля), а також суттєве збільшення за період між дослідженнями кількості заможних покупців і конкуренції (економічний чинник); збільшення загального обігу на арт-ринках творів мистецтва та підвищення суспільного інтересу до них (мистецький чинник); поява більшої, ніж у минулі часи, кількості художніх напрямів, назвемо їх узагальнюючим терміном «модернізму». На думку багатьох авторів, зокрема П. Доссі, Ф. Хука та С. Скатерщикова, мода на зазначені сучасні твори відволікає увагу покупців від давніх класичних творів, виникає запекла конкуренція, а це суттєво впливає на темпи зростання вартості останніх, підвищуючи величину їхньої вартості аж до $70 \%$ річних і більше. Загалом треба зауважити, що до наведених 
тут результатів треба ставитись обережно, оскільки вони ще не мають масової експериментальної апробації, а тому потребують додаткової перевірки й можуть застосовуватись, скажімо, оцінювачами культурних цінностей виключно як засоби експреспрогнозування.

На тлі рейтингів продажу найдорожчих картин на світових ринках цікаво було простежити можливі рейтинги української спільноти художників. Для цього, застосувавши формулу (2), була побудована таблиця (див. табл. 2) рейтингу робіт десяти українських авторів, які працювали у радянські часи й картини яких створені у 1945-1989 роках. (Зрозуміло, що український живопис другої половини ХХ ст. не обмежується тільки картинами цієї десятки).

Дані табл. 2 свідчать, що в 2011 році за характером річних швидкостей зростання вартості рейтинг, вищий серед інших, мали твори А. Шовкуненка, Ф. Захарова і М. Глущенка. Загалом усі значення р у таблиці є значно нижчими за значення щорічної швидкості зростання світових ринків ( $\mathrm{p}=10,58 \%)$, визначеної нами раніше, й меншими за середньостатистичне значення 2016 року - 11,33, визначеного вище у табл.1.

Наведені факти дають підстави для висновку про уповільнену, порівняно з світовою, динаміку зростання українського ринку.
Щоб уявити можливі довгострокові тенденції зміни вартостей робіт, котрі увійшли до табл. 2, проаналізуємо на прикладі одного з художників, які очолюють рейтинг, наприклад, М. Глущенка (до речі, його твори серед тих, що найбільше подобаються авторові), результати продажу його робіт у 1989-2017 роках.

Найдорожчий продаж робіт художника відбувся 2017 року. На аукціоні Sotheby's в Англії його твір Composition (Two Nudes) було продано за 125978 доларів США. Декілька робіт у різні роки було продано по ціні близько 20000 доларів США на аукціонах у Швеції, Франції, Англії й Україні («Дукат», «Золотий перетин»). Вартість інших робіт була значно меншою. Загалом, ціни робіт художника коливаються; перманентного їх зростання не спостерігається, отож виняток становить єдиний високий продаж, здійснений у 2017 році.

В 2009 році у свідомості світових фахівців відбулося відокремлення українського арту від російського: йдеться про окремі торги робіт українських авторів на Sotheby’s. Відтоді минуло десять років, i ми можемо проаналізувати динаміку дії цього фактора на прикладі продажу творів українських митців на світових ринках за цей період. Л. Дубовецька проаналізувала вибірку з 514 аукціонних прода-

Таблиия 2. Рейтинг творів українських авторів

(впорядкування за зростанням значення р) (Платонов, Мазур 106)

\begin{tabular}{|l|c|c|c|c|}
\hline \multicolumn{1}{|c|}{ Автор картини, назва } & $\begin{array}{c}\text { Рік створення } \\
\text { оцінки }\end{array}$ & $\begin{array}{c}\text { Вік твору до } \\
\text { оцінювання (n) }\end{array}$ & $\begin{array}{c}\text { Ціна твору } \\
\text { або естімейт } \\
\text { (тис. дол.) S }\end{array}$ & $\begin{array}{c}\text { Річна швид- } \\
\text { кість зростан- } \\
\text { няртості (p) }\end{array}$ \\
\hline С. Григор’єв «Піонер» & $1951-2011$ & 60 & $11^{*}$ & 4,0 \\
\hline А. Эрделі «Пастушка» & $1930-2011$ & 81 & $45^{*}$ & 4,7 \\
\hline $\begin{array}{l}\text { Т. Яблонська } \\
\text { «На лісовій галявині» }\end{array}$ & $1959-2011$ & 52 & $20^{*}$ & 5,8 \\
\hline А. Коцка «Верховинка & $1970-2009$ & 39 & 12 & 6,4 \\
\hline в червоній хустці» & $1956-2010$ & 54 & 35 & 6,6 \\
\hline И. Бокшай «На шляху» & $1961-2011$ & 50 & $40^{*}$ & 7,4 \\
\hline В. Цвєткова «Весняний ранок» & $1956-2011$ & 55 & $70^{*}$ & 7,7 \\
\hline С. Шишко «Вид на Аю-Даг» & $1953-2011$ & 58 & $90^{*}$ & 7,8 \\
\hline $\begin{array}{l}\text { М. Глущенко «Володимирська } \\
\text { гірка» }\end{array}$ & $1976-2009$ & 33 & 15 & 8,2 \\
\hline Ф. Захаров «Останній сніг» & $1970-2011$ & 41 & $30^{*}$ & 8,3 \\
\hline А. Шовкуненко «Букет троянд» & & & & \\
\hline
\end{tabular}


Таблиия 3. Рейтинг продажів на аукиіонах творів сучасних українських авторів за даними Artprice 2016 року (Дубовецька 66)

\begin{tabular}{|c|c|c|c|}
\hline Анатолій Криволап & $28,2 \% ;$ & Олександр Гнилицький & $2,3 \% ;$ \\
\hline Олег Тістол & $17,3 \% ;$ & Ілля Ісупов & $1,8 \% ;$ \\
\hline Арсен Савадов & $7,0 \% ;$ & Оксана Мась & $1,8 \% ;$ \\
\hline Сергій Братков & $4,9 \% ;$ & Юрій Соломко & $1,6 \% ;$ \\
\hline Олександр Ройтбурд & $4,7 \% ;$ & Олег Голосій & $1,6 \% ;$ \\
\hline Ілля Чічкан & $4,5 \% ;$ & Вінні Реунов & $1,4 \% ;$ \\
\hline Віктор Сидоренко & $4,3 \% ;$ & Ксенія Гнилицька & $1,4 \% ;$ \\
\hline Максим Мамсиков & $3,9 \% ;$ & Назар Білик & $1,2 \% ;$ \\
\hline Олександр Животков & $3,7 \% ;$ & Василь Цаголов & $1,2 \% ;$ \\
\hline Матвій Вайсберг & $2,9 \% ;$ & Дмитро Кавсан & $1,2 \% ;$ \\
\hline Роман Мінін & $2,5 \% ;$ & Михайло Деяк & $1,0 \% ;$ \\
\hline
\end{tabular}

жів сучасних українських художників 3 ресурсу Artprice за 2016 рік.

Природно, що твори сучасного мистецтва продаються не лише на аукціонах. Левова частка ринку це галерейні продажі, особисті продажі в майстерні художника тощо. Однак «легальні» дані, які супроводжують аукціонні продажі, безперечно, мають привертати максимальну увагу. У табл. 3 зазначені дані 22 художників, сумарна особиста кількість проданих робіт яких перевищує 1\% від загальної кількості 514 творів.

Як бачимо, у перших трьох рядках рейтингу йдуть прізвища А. Криволапа, О. Тістола і А. Савадова, причому відсоток участі робіт в аукціонах перших двох художників на порядок вищий, аніж у решти їхніх колег. Найдорожчий продаж робіт А. Криволапа відбувся в 2013 році: його твір «Кінь. Вечір» на аукціоні Phillips в Англії було продано за 187339 доларів США. Дві роботи в різні роки були продані на суму близько 100000 доларів США. Сплески цін на його картини припадають на 2011 та 2013-2014 роки. Картини продавалися на аукціонах в Німеччині, США, Англії й Україні («Дукат», «Золотий перетин»). За результатами наведеного рейтингу слід констатувати, що А. Криволап є найдорожчим і найпопулярнішим українським художником сучасності.

Лідерами серед аукціонних домів, на яких у 2016 році відбулися торги 514 творами сучасних українських художників є (у відсотках): Phillips 19,3; Weidler - 13,8; Sotheby - 11,3; «Золотий перетин» - 8,4; «Дукат» - 3,9 (Дубовецька 68).
Головні висновки. Для аналізу економічної складової цінності творів мистецтва в статті запропоновані кількісні характеристики їхньої привабливості.

1. У рамках порівняльного підходу запропонований варіант методу повторних продажів - простий для розрахунків і наочний в аналізі. Він базується на уявленні про експоненціальну зміну у часі вартості творів мистецтва, що описується експоненціальною моделлю зростання вартості (ЕМ3). Можлива зміна майбутньої межі періоду дослідження є важливим здобутком методу.

2. На базі моделі ЕМЗ із залученням даних про продаж у 2016 році ста найдорожчих у світі творів мистецтва розраховані рейтинги їхньої прибутковості, що дозволило проаналізувати розбіг значень цих величин, порівнювати їх з результатами, що отримані раніше іншими авторами, а також ввести обмежувальні для застосування методу значення. Досвід проведення розрахунків проілюстрував простоту застосування моделі й практичну придатність отриманих результатів.

3. Для українського арт-ринку розраховані рейтинг десяти «класиків» українського соцреалізму та дані про результати продажу на світових аукціонах творів 22 сучасних українських художників. Вибірку для останніх зроблено з понад 514 прецедентів продажу.

Перспективи використання результатів дослідження. Математична модель, запропонована в публікації для обчислення вартості творів мис- 
тецтва, теоретично є найбільш ефективною порівняно $з$ іншими моделями, спрощує проведення необхідних розрахунків, забезпечуючи їхнє істотне прискорення, а в підсумку дає можливість суттєво полегшити процес аналізу прибутковості творів мистецтва.

Результати досліджень можуть бути корисними для оцінювачів й аналітиків арт-ринків.

\section{Цитовані праці}

Досси, Пирошка. Продано! Исскуство и деньги. Пер. Евгений Волковыский. СПб.: Лимбрус Пресс, ООО«Изд-во К.Тублина», 2011. Печать.

Дубовецька, Лара. Мистецтвознавчі аспекти прогнозування оціночної вартості творів сучасного мистецтвва на ринку України. Магіст. робота. Нац. акад. керівних кадрів. культури і мистецтв. 2017. Київ: НАКККіМ. Друк.

Ігнатов, Свген. Ціноутворення об’єктів образотворчого мистецттва: практика та огляд теоретичних підходів до оцінки. Магіст. робота. Нац. акад. керівних кадрів. культури і мистецтв. 2018. Київ: НАКККіМ. Друк. Платонов, Борис. «Оценка культурных ценностей - методы сравнительного подхода». Оценочная деятельность 3-4 12 (2011): 68-71. Печать.

Платонов, Борис, Вікторія Мазур. «Огляд ринків й прогнозування оціночної вартості художніх творів (Частина І. Світові ринки)». Вісник Національної академії керівних кадрів культури і мистецтв 4 (2017): 106 - 13. Друк.

Ратникова,Татьяна, Елена Сергеева. «Оценивание гедонистической ценовой функции для картин Клода Моне». Прикладная эконометрика 4 (20) (2010): 102-18. Печать.

Скатерщиков, С. и др. Руководство по инвестированию на рынке искусства. Москва: Альпина Бизнес Букс, 2006. Печать.

Хук, Филип. Завтрак у Sotheby's: Мир искусства от А до Я. Пер. Вера Ахтырская. СПб.: Азбука, Азбука-Артикус, 2015. Печать.

«Art as an Investment and Conspicuous Consumption Good By Benjamin R. Mandel». American Economic Review 99.4 (20069): 1653-63. Print.

Artprice. Web. 17 Dec. 2018. <http://www.artprice.com/artprice-reports/the-contemporary-art-market- report2016/2015-2016-synopsis 03.02.2016>.

Arvin, M., M. Scigliano. «Hedonic prices in art and returns to art investment: Evidence from the Group of Seven at auction». Economie Appliquee 5 (7) (2004): 137-62. Print.

Baumol, W. J. «Unnatural value: Or art investment as floating crap game». American Economic Review Papers Proceeding 76 (2) (1986): 1-14. Print.

Pesando, J. «Art as an investment. The market for modern prints». American Economic Review 83 (5): $1075-89$. Print.

Throsby, D. «The Production and Consumption of the Arts: A View of Cultural Economics». Journal of Economic Literature 1 (Vol. 32) (1994): 1-29. Print.

\section{References}

Dossi, Piroshka. Prodano! Isskustvo $i$ dengi. Per. Evgeniy Volkovyiskiy. SPb.: Limbrus Press, OOO «Izd-vo K.Tublina», 2011. Pechat.

Dubovecz'ka, Lara. My’stecztvoznavchi aspekty’ prognozuvannya ocinochnoyi vartosti tvoriv suchasnogo my`stecztva na ry`nku Ukrayiny`. Magist. robota. Nacz. akad. kerivny’x kadriv. kul`tury`i my`stecztv. 2017. Ky'yiv: NAKKKiM. Druk.

Ignatov, Yevgen. Cinoutvorennya ob'yektiv obrazotvorchogomy’stecztva:rakty ka ta oglyad teorety'chny’x pidxodiv do ocinky`. Magist. robota. Nacz. akad. kerivny`x kadriv. kul`tury` i my`stecztv. 2018. Ky`yiv: NAKKKiM. Druk. Platonov, Boris. «Otsenka kulturnyih tsennostey - metodyi sravnitelnogo podhoda». Otsenochnaya deyatelnost 3-4 12 (2011): 68-71. Pechat. 
Platonov, Bory`s, Viktoriya Mazur. «Oglyad ry’nkiv j prognozuvannya ocinochnoyi vartosti xudozhnix tvoriv (Chasty’na I. Svitovi ry’nky')». Visny’k Nacional 'noyi akademiyi kerivny’x kadriv kul 'tury’ i my’stecztv 4 (2017): 106 - 13. Druk.

Ratnikova,Tatyana, Elena Sergeeva. «Otsenivanie gedonisticheskoy tsenovoy funktsii dlya kartin Kloda Mone». Prikladnaya ekonometrika 4 (20) (2010): 102-18. Pechat.

Skaterschikov, C. i dr. Rukovodstvo po investirovaniyu na ryinke iskusstva. Moskva: Alpina Biznes Buks, 2006. Pechat.

Huk, Filip. Zavtrak u Sotheby's: Mir iskusstva ot A do YA. Per. Vera Ahtyirskaya. SPb.: Azbuka, Azbuka-Artikus, 2015. Pechat.

«Art as an Investment and Conspicuous Consumption Good By Benjamin R. Mandel». American Economic Review 99.4 (20069): 1653-63. Print.

Artprice. Web. 17 Dec. 2018. <http://www.artprice.com/artprice-reports/the-contemporary-art-market- report2016/2015-2016-synopsis 03.02.2016>.

Arvin, M., M. Scigliano. «Hedonic prices in art and returns to art investment: Evidence from the Group of Seven at auction». Economie Appliquee 5 (7) (2004): 137-62. Print.

Baumol, W. J. «Unnatural value: Or art investment as floating crap game». American Economic Review Papers Proceeding 76 (2) (1986): 1-14. Print.

Pesando, J. «Art as an investment. The market for modern prints». American Economic Review 83 (5): 1075-89. Print.

Throsby, D. «The Production and Consumption of the Arts: A View of Cultural Economics». Journal of Economic Literature 1 (Vol. 32) (1994): 1-29. Print. 